\title{
THE DIRECTIONS OF FORMATION OF MORAL QUALITIES IN THE REQUIREMENTS OF MODERN ERA
}

Mushfig Mustafayev ${ }^{1}$

\begin{abstract}
The article has been investigated the dynamics and different aspects of moral qualities of student youth. This article is focused on the research of moral qualities in various investigations, and psychological mechanism of formation of moral qualities is explained .In the result of the research, it is determined that the formation of the values bears relative character, as well as it could go in the direction of positive and negative with the effect of situative factors. It became clear to us from this study, adequate self assessment of requirements create conditions to the positive strengthening of moral qualities. As well as, the attitude of students to the teaching, nonstandard approach of moral qualities to the situation could play specific role in the progress of moral qualities.
\end{abstract}

Keywords: modern era, values, teaching, student, moral, personality, self-assessment, society.

\section{Introduction:}

It should be noted that the formation of moral qualities is one of the indicators of psychological status of the personality and stipulates its formation. The appearance of moral qualities in youth, its formation, most of all, is depending on what level of the existence normative rules, standards in society of youth. Today the young should be formed as character who could cope with honor of the most important issues to be settled. These social, economical, national and moral changes first of all, require defining of the main point of activity areas, the way of thinking, the circle of knowledge and interest. Because the modern level of our development highlights the national consciousness, national belief, a sense of

\footnotetext{
${ }^{1} \mathrm{Ph} . \mathrm{D}$, associate professor, Department of Social and Pedagogical Psychology of Baku State University, Baku, Azerbaijan. Email: mustafayev76@mail.ru. ORCID: https://orcid.org/0000-0002-8954-9635.
} 
dignity. The increase of the interest of learning the system of moral qualities of the young comes from this necessity. Of course, youth plays important place by the their nature in the public structure of society .Nowadays focusing on the positive the direction of the system of moral values becomes a necessary requirement in the young who are the driving force in public life of the society.
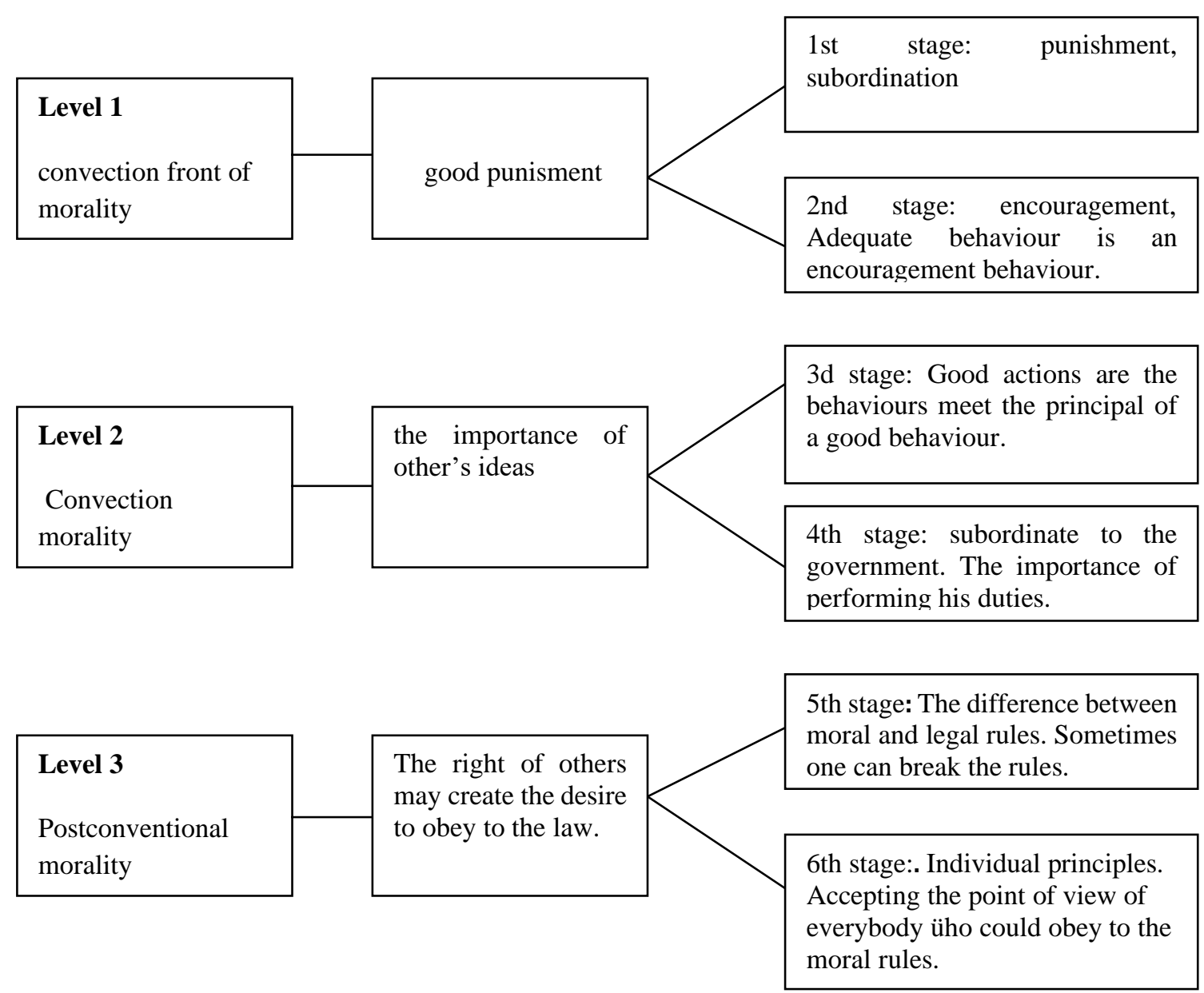

\section{Picture1. Moral-ethic progress( according to Kohlberg)}

American psychologist who

researches the moral qualities notes that that it has passed 6 stages. (L.Kohlberg 1963). Kolberg thinks that the first stage is the period of hearing and being aware of the punishment. Children directly demonstrate subordination characteristics in these stages. Here the 
basics of spiritual developments begin from the imaginations about moral qualities. We think that the formation of the conceptions of badness and goodness at children are the main attributes of their moral values. As you can see Kolberg approaches to these issues from another aspect.(graphic 2)

In the second stage children understand that the moral principles the are not the same moral principles for everybody.

In the third stage teenagers understand that true behaviour form promises them some of the reward. In the fourth stage Kolberg identifies the moral development ith the ethic development. Surely, we couldn.t agree with Kolberg's thoughts. It is necessity to make attention to some of the issues while analysing Kolberg's theory.

Besides Kolberg, the outstanding psychologist C.Piace also tried to learn this issue in his lwriting. Piace's theory reminds us Kolber's theory for the content and methodology. Piece thinks that 1st one is a partnership stage and the second one is transitional stage. The matter he has noted in the folloüing is reflected as other $\mathrm{He}$ believes that moral development appears on the basis of ethic judgments and go through on stages. In his opinion, teenagers with 11-12 aged make other kind of judgments about morality and spirituality on comparison of the older teenagers. (J.Piaget, 1932). This issue was described completely different in the theory of Kolberg as we mentioned earlier. He thinks that little children understand the moral rules as a law. They believe that the moral rules were made by either their parents or the God and it's impossible to change them. Teenagers value more real the moral qualities comparison with the elders. Piace's theory was devoted to the moral development reflects the other details on itself.

The conceptions relating to the moral development we noted ahead haven't been greeted unconditionally by everybody. Because there would have specific lacks tin these researches. The outstanding researcher H.Gilligan who tries to clear this issue shows that the moral development theory of Kolberg really doesn't reflects the completely differential differences of sex differences. He believes that Kolberg made the classified stages from the interview with the boys and this 
conception reflects two directions apparently on itself. (Gilligan, 1977) It is known that moral qualities in men is directly related to norms, rules and abstract principles. Formal justice principle acts in ideal role here. Individual doesn't go far from the situation in the difficult situations and corresponding to its theoretical relationships and the principle considering fair he attempts to find a moral solution. İn his opinion these conceptions as mentioned above doesn't reflect women's outlook and their relationships for some questions in itself. He believes that the opinions about spirituality has not been made on norms and rules but interpersonal relationships and care and ethics of difficulties. Their ideal is not a formal justice but generalized life image. Therefore, the issue of spirituality in women is depend on which aspect they approach the issue and above all it has been characterized with the real-changing relationships. Especially due to this gender difference men and women fall into various stages in Kolberg scale. In case of women place in the focus of interpersonal conception, basically they fall into the third stage, but men place in the fourth and fifth stages which describes more abstract conception of social forming. As we see, there are a lot of right comments in research of this conception. Gilligan tries to show the orientation of moral development in women. He believes that the imaginations of women about care and claim welded from the real life situations. He had opinion and profile inquiries with women who get into difficult situations. The results of these inquiries demonstrate that the moral orientation of women in conventional and conventional frontal stage is based on the post conventional mentality model. Women like to speak about the private interests that more important for them in conventional frontal stage. Their position in the conventional level is introduced as a person who depends on the society completely and a careful mother, the feeling of motherhood. They formalised their private ideas emerging from the human relationships in the post conventional stage. (Gilligan 1983) Another researcher Uolker who made disccussions with women notes that the most disturbing aspect in moral development for them is the issues of responsibility and selfishness. The emphasis relating to the first aspect is 
directed to the personality of the human and the responsibilty feeling in front of others in the second stage. Üe could see it clearly in the folloüing example. A woman named Kler writes: The life has no meaning when the person is alone, it's just like a voice of one hand, you should love somebody, you should separate from them. In some cases, it reminds the love of human to his right hand. It is one part of yours".

If we analyze these issues broadly, we could decide that the formations directions of moral development differ in woman and men in terms of the concept. As you can see men tries to explain the spirituality concept from the irrational position and women explain it on the basis of the position between themselves and others. Due to the surveys condcuted by The outstanding researcher Vernerin two clear lines of moral development draws attention. The first line manifests more to the justice and logic, the second one manifests in realtion of concerns. Let's summarize what we say, we can conclude that the formation of the moral development is not defined only with ethnic, national and individual characters, but also differs in respect of the concept this issue differs from the ground of gender differences.

The experience shows that the upbringing of intellect has been preferred in comparing to the moral upbringing in modern condition.İn result, moral corrosion emerges in society. The number of researchers who valued the role of archetypes in the progress of the moral formation wasn't a little. Z.Freyd archetype explains as a universal form combines the emothional element significantly in itself. He notes that it creates the images relating to some opportunities of simple life. For Z.Freid, the archetypes penetrate to one another and differentiate. Myths, dream and culture examples and etc. Embracing the archetypic material in itself is the best expression of our knowledges about archetypes. All of them accompanies the human during the moral development. Therefore, K.Yunq, S.Khill, T.Lindset, J.Kelly and other researchers emphasised the opinion of taking a certain role of archetyoes in moral development. The famous scientist K.Yung thinks that neü born child is not a tabula rassa. As well he gets older, congenital inclinations determining his behaviour directions find its 
position.(K.Yung 1920) He called these inclinations as archetyopes. Saying about archetypes, they are understood as the extremely complicated relations that find their position directly in human consciousness, and images, desires, behavioral forms which transmitted from generation to generation. In K.Yung's opinion, archetypes show our attitude, masculinity and femininity to the animal demands, the people we communicated and to ourselves, social situation we live.

The mechanism of the moral development is formalized as selfconfirmation inMasloun's writings. In his opinion the way of revealing of the potential opportunities of an individual goes through the self-realization. $\mathrm{He}$ notes that owning the traditional values of person depends on the paying his important demands. Later the author notes that an individual refers more to his own feelings during falling under the influence of moral values systematically. Experiencing of new, appearing of new goals helps him to find his own way. In this moment the responsibility sense from moral qualities is formulated on him. An individual formulates more responsibility in himself avoiding to play comedy for protecting his image and getiing rid of the sphere of influence. Selfrespecting feeling goes well in return of these actions. Most importantly, all of them formulates him as a human who cares of them and thinks about others as a creative personality. And this shouldn't happen without owning the moral values. So, individual achieves to selfrealization -the last stage of his moral development.(A.Maslou,1970)

The main goal in the research is determining the characters in students.

\section{Research aim}

The theory of this research was grounded that the formulation of moral qualities in the student youth, their upbringing in the family and school depend on the organizing form of training-upbringing and the system of values importantly.

\section{Research Methods.}

The methodology of L.Kolberg and self-valuation test of Rozenberg has been used for measuring the moral qualities in the students' youth. The analysis of the quality and quantity has been used for checking the theory. 
200 hundred students were participated in the research.

The research was performed on the students of Baku State University.The participants of the research were $50 \%$ of women and $50 \%$ men.

\section{Discussion}

The results of the methodologies performed on the Kolberg's methodology with 17-19 aged students was described in three criterions. İt became clear form here that the question of good learners "Theft is illegal. How do you think is it false in respect of morality?" the $52 \%$ consdired it true action, $28 \%$ considered it false, but the $30 \%$ noted that it depends on the situation. The number of learners who considered it false behaviour in respect of morality was $53 \%$ about answering this question in learners of low marks.

How do you value the behavior in spirituality?

Table 1.

\begin{tabular}{|c|c|c|c|c|c|c|}
\hline \multicolumn{6}{|c|}{$\begin{array}{l}\text { The situation in education. How do you value the behavior in } \\
\text { respect of morality? } \\
\qquad \text { *Gender Cross tabulation }\end{array}$} & \multirow[t]{2}{*}{ TOTAL } \\
\hline \multirow{5}{*}{$\begin{array}{l}17-19 \\
\text { aged }\end{array}$} & & & $\begin{array}{l}\text { Depending } \\
\text { on the } \\
\text { situation }\end{array}$ & False & true & \\
\hline & \multirow[t]{3}{*}{ Girl } & $\begin{array}{l}\text { Studies } \\
\text { well }\end{array}$ & 4 & 9 & 3 & 16 \\
\hline & & $\begin{array}{l}\text { Studies } \\
\text { well }\end{array}$ & 5 & 5 & 7 & 17 \\
\hline & & $\begin{array}{l}\text { Studies } \\
\text { excellent }\end{array}$ & 3 & 5 & 9 & 17 \\
\hline & Boy & $\begin{array}{l}\text { Studies } \\
\text { badly }\end{array}$ & 3 & 10 & 3 & 16 \\
\hline
\end{tabular}




\begin{tabular}{|l|l|l|l|l|l|l|}
\hline & $\begin{array}{l}\text { Studies } \\
\text { well }\end{array}$ & 4 & 5 & 8 & 17 \\
\cline { 2 - 7 } & $\begin{array}{l}\text { Studies } \\
\text { excellent }\end{array}$ & 3 & 5 & 9 & 17 \\
\hline
\end{tabular}

The analysis with 17-19 aged students of Kolberg methodology show that the true valuation of the action in respect of spirituality depends on the outlook, intellectual level and sphere of knowledge of students. So, $52 \%$ of girls, and 565 of boys consider true in spirituality the abovementioned question. The certain differences between the boys and girls of studying badly.

Table 2. How do you value the action by spiritually?

\begin{tabular}{|c|c|c|c|c|c|c|}
\hline \multicolumn{6}{|c|}{$\begin{array}{l}\text { The situation in education. How do you value the action in } \\
\text { spiritually? } \\
\qquad * \text { Gender Cross tabulation }\end{array}$} & \multirow[t]{2}{*}{ TOTAL } \\
\hline \multirow{6}{*}{$\begin{array}{l}20-22 \\
\text { aged }\end{array}$} & & & $\begin{array}{l}\text { Depending } \\
\text { on the } \\
\text { situation }\end{array}$ & False & true & \\
\hline & \multirow[t]{3}{*}{ Girl } & $\begin{array}{l}\text { Studies } \\
\text { well }\end{array}$ & 4 & 10 & 2 & 16 \\
\hline & & $\begin{array}{l}\text { Studies } \\
\text { well }\end{array}$ & & 7 & 8 & 17 \\
\hline & & $\begin{array}{l}\text { Studies } \\
\text { excellent }\end{array}$ & 1 & 6 & 10 & 17 \\
\hline & \multirow[t]{2}{*}{ Boy } & $\begin{array}{l}\text { Studies } \\
\text { badly }\end{array}$ & 4 & 9 & 3 & 16 \\
\hline & & $\begin{array}{l}\text { Studies } \\
\text { well }\end{array}$ & 3 & 6 & 8 & 17 \\
\hline
\end{tabular}


The results of the research with 20-22 aged students conducted by Kolberg methodology show that justifing to some actions in spirituality as getting older demonstrates itself sharply. It becames clears from the analysis of the research the number of girls who considered true the action in spirituality was $40 \%$. This number in boys was higher with $44 \%$. This show that the valuation of moral actions and justifying them according to the age goes on the increasing line. In contrary to this, as the age gets older the valuation of the actions depending on the situation goes on decreasing line.For example, if this number at $17-19$ ages is $24 \%$ and $20 \%$, it is $14 \%$ and $16 \%$ in $20-22$ ages. This shows that the character of the attitude to the training determines the direction of moral development in some cases. Because most of the excellent students perefers the spiritual actions which considered beneficial for the society mostly expressing the attitude to others. Preferring the qualities that expressing their individuality mostly of bad learner students proves that choosing true upbringing principles and creating training motives are necessary.

The character to the training of the attitude has great importance in direction of selfconfirmation of students in terms of realising the intended goal. So, in the situation of valuing separately of spiritual actions boy students had higher indexes than girls. This fact shows that as the age gets older spiritual improvement process formulates in concrete direction. İf the causes of the valuation of spiritual actions were stipulated with different factors in previous age periods, the students coordinated the idea of being false of other spiritual actions with concrete causes in later age periods.

The results of the research with 20-22 aged students conducted by Kolberg methodology showed that being true or false of the action depending on the situation was valued by the $4 \%$ of excellent learners from boys, $1 \%$ of good learners and $12 \%$ of bad learners. As we 
can see bad learners of boy students identificated directly the aspects of their personalities of false actions. We can conclude that spiritual improvement process goes through two levels: either differentiation or the identification way. Additional conversations with the students show that there is a great role of the group the young studies. Such kind
516 of actions wins the first place mostly in the groups with excellent students, so those actions correspondence to the position the same group. Here we should note the great importance of standards and models. Because the rules of actions which are the true spiritually for some could be considered false spiritually for others.

Table 3. The situation in education* How do you value the action by spiritually?

\begin{tabular}{|c|c|c|c|c|c|c|}
\hline & & $\begin{array}{r}\text { do you v } \\
\text { spiri }\end{array}$ & $\begin{array}{l}\text { e the action in } \\
\text { lly? }\end{array}$ & & & TOTAL \\
\hline The & & & $\begin{array}{l}\text { Depending } \\
\text { on the } \\
\text { situation }\end{array}$ & False & true & \\
\hline $\begin{array}{l}\text { situation in } \\
\text { education }\end{array}$ & Girl & $\begin{array}{l}\text { Studies } \\
\text { badly }\end{array}$ & 26 & 46 & 24 & 96 \\
\hline & & $\begin{array}{l}\text { Studies } \\
\text { well }\end{array}$ & 24 & 28 & 50 & 102 \\
\hline Total & & $\begin{array}{l}\text { Studies } \\
\text { excellent }\end{array}$ & 13 & 26 & 63 & 102 \\
\hline & Boy & & 63 & 100 & 137 & 300 \\
\hline
\end{tabular}

Table 4. The index of Kolberg methodology in students

The situation in education. How do you value the action in spiritually? 
Periódico do Núcleo de Estudos e Pesquisas sobre Gênero e Direito

Centro de Ciências Jurídicas - Universidade Federal da Paraíba

V. 9 - $\mathrm{N}^{\circ} 02$ - Ano 2020

ISSN | 2179-7137 | http://periodicos.ufpb.br/ojs2/index.php/ged/index

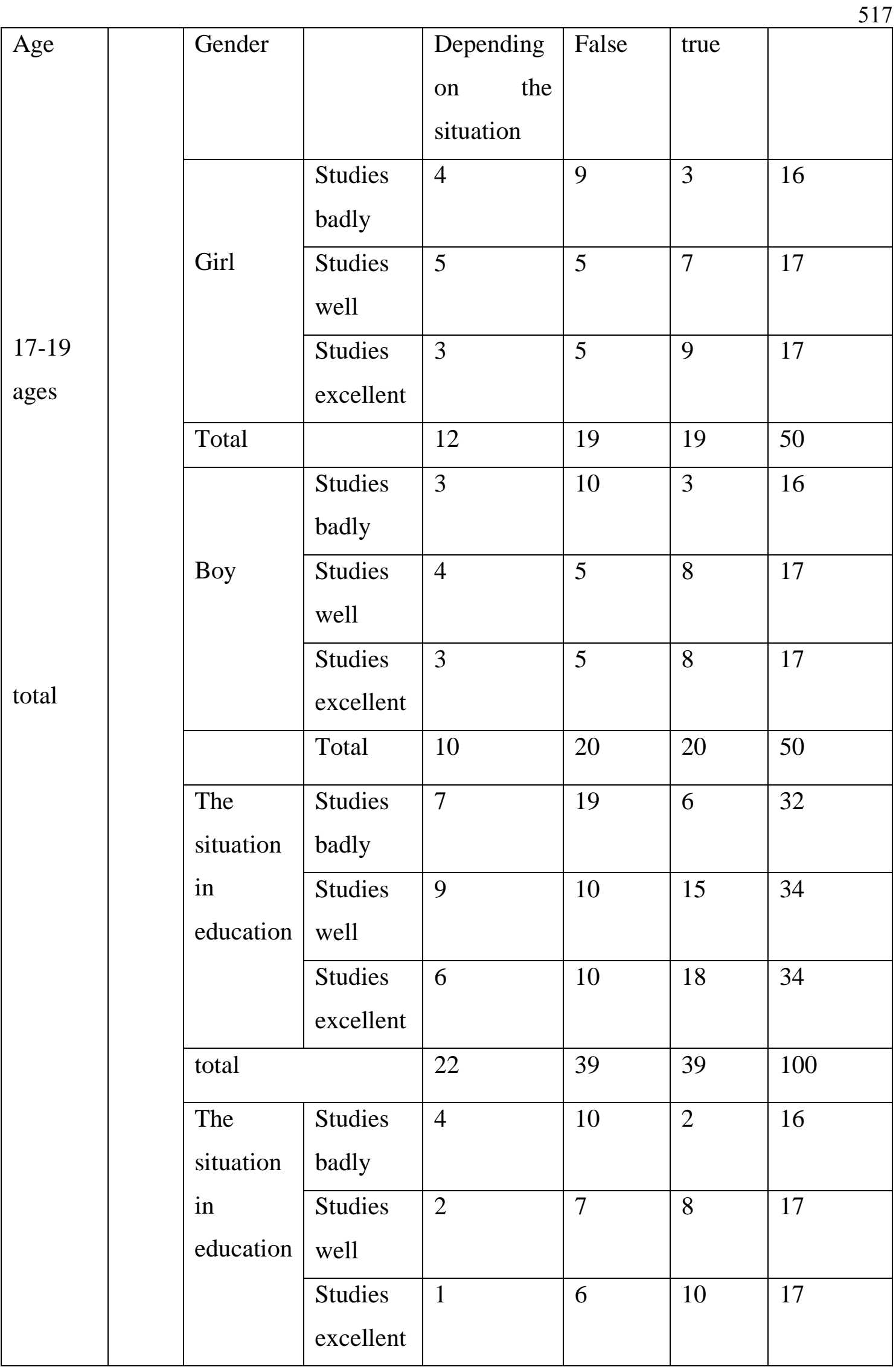


Periódico do Núcleo de Estudos e Pesquisas sobre Gênero e Direito

Centro de Ciências Jurídicas - Universidade Federal da Paraíba

V. 9 - $\mathrm{N}^{\circ} 02$ - Ano 2020

ISSN | 2179-7137 | http://periodicos.ufpb.br/ojs2/index.php/ged/index

\begin{tabular}{|c|c|c|c|c|c|c|}
\hline \multirow{3}{*}{$\begin{array}{l}20- \\
\text { 22ages }\end{array}$} & \multicolumn{2}{|l|}{ total } & \multirow{2}{*}{$\begin{array}{l}7 \\
4\end{array}$} & \multirow{2}{*}{$\begin{array}{l}23 \\
9\end{array}$} & \multirow{2}{*}{\begin{tabular}{|l|}
20 \\
5
\end{tabular}} & \multirow{2}{*}{$\begin{array}{l}50 \\
16\end{array}$} \\
\hline & $\begin{array}{l}\text { The } \\
\text { situation }\end{array}$ & $\begin{array}{l}\text { Studies } \\
\text { badly }\end{array}$ & & & & \\
\hline & $\begin{array}{l}\text { in } \\
\text { education }\end{array}$ & $\begin{array}{l}\text { Studies } \\
\text { well }\end{array}$ & 3 & 6 & 8 & 17 \\
\hline \multirow[t]{2}{*}{ Boy } & & $\begin{array}{l}\text { Studies } \\
\text { excellant }\end{array}$ & 1 & 5 & 11 & 17 \\
\hline & \multicolumn{2}{|l|}{ Total } & 8 & 20 & 22 & 50 \\
\hline \multirow{3}{*}{ Total } & \multirow{3}{*}{$\begin{array}{l}\text { The } \\
\text { situation } \\
\text { in } \\
\text { education }\end{array}$} & $\begin{array}{l}\text { Studies } \\
\text { badly }\end{array}$ & 8 & 19 & 5 & 32 \\
\hline & & $\begin{array}{l}\text { Studies } \\
\text { well }\end{array}$ & 5 & 13 & 16 & 34 \\
\hline & & $\begin{array}{l}\text { Studies } \\
\text { excellent }\end{array}$ & 2 & 11 & 21 & 34 \\
\hline \multirow{5}{*}{ Girl } & Total & & 15 & 43 & 42 & 100 \\
\hline & \multirow{3}{*}{$\begin{array}{l}\text { The } \\
\text { situation } \\
\text { in the } \\
\text { education }\end{array}$} & $\begin{array}{l}\text { Studies } \\
\text { badly }\end{array}$ & 6 & 4 & 6 & 16 \\
\hline & & $\begin{array}{l}\text { Studies } \\
\text { well }\end{array}$ & 5 & 3 & 9 & 17 \\
\hline & & $\begin{array}{l}\text { Studies } \\
\text { excellent }\end{array}$ & 3 & 2 & 12 & 17 \\
\hline & Total & & 14 & 9 & 27 & 50 \\
\hline \multirow{2}{*}{$\begin{array}{l}23-25 \\
\text { ages }\end{array}$} & \multirow{3}{*}{$\begin{array}{l}\text { The } \\
\text { situation } \\
\text { in } \\
\text { education }\end{array}$} & $\begin{array}{l}\text { Studies } \\
\text { badly }\end{array}$ & 5 & 4 & 7 & 16 \\
\hline & & $\begin{array}{l}\text { Studies } \\
\text { well }\end{array}$ & 5 & 2 & 10 & 17 \\
\hline \multirow[t]{2}{*}{ Boy } & & $\begin{array}{l}\text { Studies } \\
\text { excellent }\end{array}$ & 2 & 3 & 12 & 17 \\
\hline & Total & & 12 & 9 & 29 & 50 \\
\hline
\end{tabular}




\begin{tabular}{|l|l|l|l|l|l|l|l|}
\hline \multirow{4}{*}{} & \multirow{3}{*}{$\begin{array}{l}\text { The } \\
\text { situation } \\
\text { in } \\
\text { education }\end{array}$} & $\begin{array}{l}\text { Studies } \\
\text { badly }\end{array}$ & 11 & 8 & 13 & 32 \\
\cline { 3 - 8 } & $\begin{array}{l}\text { Studies } \\
\text { well }\end{array}$ & 10 & 5 & 19 & 34 \\
\cline { 3 - 8 } & $\begin{array}{l}\text { Studies } \\
\text { excellent }\end{array}$ & 5 & 5 & 24 & 34 \\
\hline
\end{tabular}

İn young students with 18-25 aged, the self valuation test of Rosenberg was carried out in the purpose of determining the issues of depending on the main factors of spiritual development and making out the certain correlation between theem. If we explain the received results, truely defining the moral qualities and specifying their boundaries in the age periods and groups appropriate to the standard of self valuation is adequate.

One issue especially reflected here that the development dynamics of self valuation in girls goes on the increasing line and the valuation of moral qualities goes on the decreasing line as the age increases. Contrary in boys the development dynamics of self valuation in girls goes on the decreasing line and the valuation of moral qualities goes on the increasing line as the age increases. As well,the certain relations between the ability to determine truly the moral qualities of good and bad learner students and their self-valuation were found out.

\section{Conclusions}

We could come to this conclusion from the general analysis that what level of students' imaginations about themselves and their attitude to the same imaginations take great role in the formation of the moral qualities. Itt means that acting from the demands of the social situation and the imaginations about their personality the students values the actions separately beaing true or false in spiritually.

In our opinion the above mentioned shouldn't be overlooked, and give oppotunies to adequate attitude to themselves in training and upbringing process.Generalizing the results received from the Kolberg's method, we tcould 
conclude that the development of moral qualities in young students shows itself in three directions. These are the followings: 1. Dynamic level 2. Situative level 3. Regular level. İn the first level, the valuation of the spiritual actions doesn't differentiate in the ground of gender differences, the change for age, especially the attitude to the training. This level shows itself continuesly in young students. In most cases the youngs from this age the disportion between considering true and false of different moral actions is very little.. The comment inquieries later conducted showed that the cause of this is related to not uunderstanding adequately in necessary level of moral qualities in the same age period. But in addition to that we should note one issue that this shows itself not only in 17-19 aged students but also in other age periods. But this level shows itself a little at 20-22, 23-25 ages.. And this is related to going toüards to stabilization of attitude to the moral qualities.

The second level is situative level. This level shows itself distinctly at 20-22 aged students. And it should be explained with the age characteristics of young students. Non-formalizing of selectivity of attitude to the separate incidents, as well as the nonunderstanding of the last purpose doesn't allow the creation of regular attitude to these qualities in absolute sense of them.

The third level is regular level and the attitude ro moral qualities in this level doesn't change though the various presentations. Namely keeping adifferent places during the assignment with various questionaries, inquieries of the same qualities shows that the imaginations about the moral qualities of young students with 23-25 ages is unchangeable and the imagionations of what is good or bad had strenghtened. It's already impossible the distortion of some elements that sthrengthened in earlier age periods.

\section{Literature}

Alport, Vernon, Lindzu(1970). Manual of values. Copyrught by Hogustton

Jabbarov R.(2017). Factors affecting the development of self-realization among students of different professions. Science and Education, 9, 75-87. 10.24195/24144665-2017-9-12.

Jabbarov R.; Mustafayev, 
$\underline{\mathrm{M}}$; Kazimova, K $; \underline{\text { Valiyeva, Y }}$ (2018)

.Factors affecting students' professional identity, .science and education, dOi: $10.24195 / 2414-4665-2018-1-5$

Swader, C. S. (2013). The capitalist personality: Face-to-face sociality and economic change in the post-communist world. New York: Routledge.

Mustafayev M.H. (2019) Dynamics of changing of wealth tendencies in students of different specialties. Revista Dilemas Contemporáneos: Educación, Política y Valores.

Gilligan C., Wiggins G (1990).. The origins of morality in early childhood relationship // The emergence of morality in young children /J. Kagan, S. Lambs, eds. Chicago.

Vedder, P., Berry, J., Sabatier, C., \& Sam, D. (2009). The intergenerational transmission of values in national and immigrant families: The role of Zeitgeist. Youth Adolescence, 38, 642653.

Mudrik, A. V. (2000). The main components of mesofactors influence on socialization of man. In V. A. Slastenin (Ed.), Social pedagogy, pp. 31-50). Moscow: Akademiya.

Фрейд 3. (1989).Введение в психоанализу: М.: Наука, 455 с.

Kolberg L.(1970). Moral development and identification, child psychology, University of Chicago Press, P 277 - 332

Piaget, J. (1932). The moral judgment of the child. New York: Harcourt Brace 